\title{
A Presynaptic Mechanism Accounts for the Differential Block of Nicotinic Synapses on Sympathetic B and C Neurons by d-Tubocurarine
}

\author{
Wei-Xing Shen and John P. Horn \\ Department of Neurobiology, University of Pittsburgh, School of Medicine, Pittsburgh, Pennsylvania 15261
}

The effects of $d$-tubocurarine (dTC) on nicotinic synapses on sympathetic $B$ and $C$ neurons in the bullfrog were compared by recording trains of postganglionic compound action potentials (CAPs) at $0.5-20 \mathrm{~Hz}$. Block by dTC was strongly use dependent in that the $I_{50}$ shifted almost 10 fold with increasing stimulus frequency. Maximum sensitivity to dTC occurred at $5 \mathrm{~Hz}$ in the $\mathrm{B}$ system and at $20 \mathrm{~Hz}$ in the $C$ system. Recovery during posttrain periods was characterized by transient reduction of CAP amplitude in the B system and by transient enhancement of CAP amplitude in the $\mathrm{C}$ system. Thus, dTC distinguished between nicotinic synapses on the two cell types.

The cell-specific effects of dTC could arise from differences in postsynaptic or presynaptic nicotinic receptors, or from differences in acetylcholine (ACh) release. We tested these possibilities using intracellular recording. Based on comparison with lontophoretic responses to $\mathrm{ACh}$, changes in EPSP amplitude during repetitive stimulation in dTC could not be explained by altered postsynaptic sensitivity. The block of nicotinic receptors was further analyzed by recording synaptic currents. In B and C cells, 3 $\mu \mathrm{M}$ dTC competitively antagonized EPSC amplitude by $54 \%$ without any sign of open-channel block. In B cells, comparison of trains in normal Ringer and dTC revealed a constant fractional reduction in EPSC amplitude, thereby indicating that presynaptic nicotinic receptors do not influence release. In the $\mathbf{C}$ system, dTC had no effect on peptidergic EPSPs, thereby suggesting that presynaptic nicotinic receptors also do not influence peptide release.

We conclude that the differential effects of dTC on nicotinic transmission are indirect consequences of differences in $\mathrm{ACh}$ release by preganglionic $\mathrm{B}$ and $\mathrm{C}$ neurons.

[Key words: neuronal nicotinic receptors, presynaptic modulation, presynaptic nicotinic receptors, synaptic depression, sympathetic ganglia, synaptic potentiation]

These experiments were begun with the goal of identifying antagonists that could distinguish between nicotinic synapses on functionally distinct groups of sympathetic neurons. Such antag-

\footnotetext{
Received Oct. 20, 1994; revised Feb. 8, 1995; accepted Feb. 13, 1995.

This work was supported by NIH Grants RO1 NS21065 and KO4 NS01427 and a grant-in-aid from the American Heart Association, Pennsylvania Affiliate. We thank Drs. Elias Aizenman and Phillip Jobling for reading the manuscript and Ms. P. Wohlfarth for technical assistance.

Correspondence should be addressed to Dr. John P. Horn, Department of Neurobiology, University of Pittsburgh, School of Medicine, E1440 Biomedical Science Tower, Pittsburgh, PA 15261.

Copyright (C) 1995 Society for Neuroscience $0270-6474 / 95 / 155025-11 \$ 05.00 / 0$
}

onists would be useful for analyzing the integrative function of sympathetic ganglia. At the outset the possibility that antagonists might be selective appeared plausible given the cellular organization of bullfrog sympathetic ganglia and the molecular properties of neuronal nicotinic receptors in other systems.

As in higher vertebrates, bullfrog sympathetic neurons are organized into phenotypes serving specialized functional modalities (Horn, 1992; Janig and McLachlan, 1992). B neurons innervate cutaneous glands (P. Jobling and J. P. Horn, unpublished observations) and $\mathrm{C}$ neurons innervate arterics (Stofer et al., 1990). At the ganglionic level, postsynaptic nicotinic receptors mediate fast synaptic transmission in both cell types. However, the receptors on each cell type have different kinetic properties; the mean open-time of the channel is two times larger in C cells than in B cells (Marshall, 1985, 1986). This implies the existence of a structural difference between nicotinic receptors on $\mathrm{B}$ and $\mathrm{C}$ neurons.

The pharmacological subclassification of nicotinic receptors was begun by Paton and Zaimis (1949). They showed that antagonists can select between nicotinic synapses in autonomic ganglia and in muscle, and thereby provided indirect evidence that the two cell types express different nicotinic receptors. Wellknown examples from this work are that hexamethonium selectively blocks ganglionic transmission while decamethonium and $d$-tubocurarine (dTC) selectively block neuromuscular transmission. Molecular cloning has subsequently revealed that (1) nicotinic receptors on neurons and muscle are composed of different though homologous subunits (Sargent, 1993); (2) neuronal nicotinic receptors are themselves made from diverse families of $\alpha$ and $\beta$ subunits; and (3) autonomic neurons express at least five different subunits (Listerud et al., 1991; Corriveau and Berg, 1993; Vernallis et al., 1993). This implies a striking potential for receptor heterogeneity, but its actual extent and functional importance in the nervous system remain less clear. Possible implications of nicotinic receptor diversity are suggested by experiments using heterologous expression in Xenopus oocytes. In these studies the kinetic properties and pharmacology of neuronal nicotinic receptors both depend on subunit composition (Luetje et al., 1990; Luetje and Patrick, 1991; Papke and Heinemann, 1991). We therefore wondered whether the kinetic differences between receptors on bullfrog $\mathrm{B}$ and $\mathrm{C}$ cells might be accompanied by pharmacological distinctions.

Preparations of bullfrog lumbar sympathetic chain ganglia 9 and 10 arc convenient for screening antagonists because population responses of $\mathrm{B}$ and $\mathrm{C}$ cells can be easily monitored using simple extracellular recordings. During preliminary extracellular experiments it became evident that the blocking actions of dTC 
and other antagonists were indeed cell specific, and that they varied greatly with the frequency of presynaptic stimulation, especially in the B system (Shen and Horn, 1992, 1993).

This article describes extracellular experiments that document the nature and extent of cell-specific block by dTC, and intracellular experiments that evaluate three possible underlying mechanisms. In different autonomic ganglia, dTC acts to varying degrees as an open-channel blocker and as a competitive antagonist of acetylcholine (ACh) binding (Ascher et al., 1979; Rang, 1982; Lipscombe and Rang, 1988; Skok et al., 1989). One mechanism for cellular selectivity would involve differences in postsynaptic receptors. They might vary in their affinity for dTC as a competitive or open-channel blocker. A second mechanism invokes presynaptic nicotinic receptors that are thought to exist in bullfrog sympathetic ganglia (Koketsu and Nishi, 1968; Ginsborg, 1971). In principle, presynaptic nicotinic receptors could modulate transmitter release in either cell system. Finally, dTC might act indirectly to unmask a difference in the release mechanism for $\mathrm{ACh}$ by preganglionic $\mathrm{B}$ and $\mathrm{C}$ neurons.

\section{Materials and Methods}

Preparation and general procedures. Experiments were done at room temperature $\left(21-24^{\circ} \mathrm{C}\right)$ on preparations of paravertebral sympathetic ganglia 7-10 that were isolated from 6-7 inch bullfrogs (Rana catesbiana) of both sexes (Charles D. Sullivan, Co., Nashville, TN). We used established procedures for dissecting ganglia, for extracellular recording from rami communicantes with suction electrodes, and for intracellular recording from neurons visualized under a $40 \times$ water-immersion Nomarski objective (Dodd and Horn, 1983). Stimulus intensity and polarity were adjusted to evoke minimal latency responses that were supramaximal. $\mathrm{B}$ and $\mathrm{C}$ ccll responses wcre selectively evoked by stimulating the sympathetic chain rostral to ganglion 7 , and spinal nerves 7 and 8 central to their rami. Fast and slow B neurons were not distinguished in this study.

Extracellular experiments to construct dose-response relations. Paired recordings of trains of compound action potentials (CAPs) were made from the $\mathrm{B}$ and $\mathrm{C}$ cell systems over a range of stimulus frequencies $(0.5-20 \mathrm{~Hz})$ and dTC concentrations $(3-100 \mu \mathrm{M})$. These experiments were done in a low-volume chamber $(1.5 \mathrm{ml})$ at a superfusion rate of 4-6 ml/min. In control experiments, the effects of 10 and 100 $\mu \mathrm{M}$ dTC were found to equilibrate in $<30 \mathrm{~min}$. The protocol for doseresponse experiments was therefore to wait $30 \mathrm{~min}$ for $\mathrm{dTC}$ to equilibrate, to record $\mathrm{B}$ responses in ascending order of frequency, to record a set of $\mathrm{C}$ responses, and then to repeat the sequence at the next higher dose. The waiting time betwecn stimulus trains was another factor in the experimental design. Forty stimuli, especially at higher frequencies, may evoke slow postsynaptic potentials, presynaptic potentiation, and presynaptic depression (Zengel et al., 1980; Horn, 1992). To minimize these factors, 2.5 min rests were included between trains.

During initial experiments extracellular CAPs amplitudes were measured from chart records (Gould 2400). In subsequent experiments the signals were digitized at $2 \mathrm{kHz}$ with a Digidata 1200 interface utilizing AXOTAPE 2.0 software and a Dell 486DX/33 computer. Data were then transferred to a Macintosh computer and analyzed using IGOR software (Wavemetrics, Lake Oswego, OR).

$\mathrm{IC}_{30}$ values were estimated by fitting dose-response data to a logistic equation (DeLean et al., 1978) with IGOR (normalized responses for blockade at zero and infinite dTC concentrations were held constant at 1 and 0 ). $\mathrm{IC}_{50}$ values for the $\mathrm{B}$ and $\mathrm{C}$ systems were compared using Student's paired two-tailed $t$ test and $p<0.05$ as the criterion for significance.

Intracellular recording and voltage clamp. Synaptic potentials and responses to acetylcholine were recorded intracellularly under current clamp (Harris et al., 1971; Dodd and Horn, 1983). Electrodes were pulled from $1.2 \mathrm{~mm}$ glass on a Narishige PD-5 puller or a Sutter P-87 puller. Intracellular electrodes $(3 \mathrm{M} \mathrm{KCl})$ had resistances of $60-120 \mathrm{M} \Omega$. Iontophoretic electrodes were pulled at the same settings and filled with $1 \mathrm{M}$ ACh. The ACh pipette was pressed against the surface of a cell body and briefly oscillated to lessen diffusion barriers. Backing currents of 1-5 nA were sufficient to prevent $\mathrm{ACh}$ leakage and receptor desensitization. dTC was bath applied in Ringer at $1-4 \mathrm{ml} / \mathrm{min}$.
Nicotinic EPSCs were recorded under two-electrode voltage clamp using an Axoclamp-2A or B amplifier. Electrodes were beveled to $20-$ $30 \mathrm{M} \Omega$ (Sutter BV-10). Clamp data were accepted only when EPSCs were free of notches and the unclamped potential was less than $3 \mathrm{mV}$. No correction was made for the voltage error.

In some experiments the voltage dependence of synaptic currents was measured by jumping the holding potential from $-50 \mathrm{mV}$ to between -100 and $+80 \mathrm{mV}$. During these experiments synaptic currents were evoked at low rates $(0.1-0.2 \mathrm{~Hz})$ and holding potential was shifted using $850 \mathrm{msec}$ pulses. Synaptic currents were stimulated $400 \mathrm{msec}$ after the start of the pulse to avoid contamination by voltage-sensitive currents. Generally five successive synaptic currents were averaged at each potential to minimize signal fluctuations. In experiments using stimulus trains, the holding potential was manually adjusted.

Voltage and current signals were low-pass filtered at 3 and $1-1.3$ $\mathrm{kHz}$. They were monitored on an oscilloscope and digitized at 2.5-5 $\mathrm{kHz}$ using the same computer and software as for extracellular experiments. Using IGOR, averaged synaptic current amplitudes were measured, and time constants of EPSC decay were estimated by fitting data between $90 \%$ and $10 \%$ of the peak to one exponential.

Intracellular data from $\mathrm{B}$ and $\mathrm{C}$ neurons were compared using Student's unpaired two-tailed $t$ test and $p<0.05$ as the criterion for significance.

Solutions and drugs. The Ringer solution contained (mM) $115 \mathrm{NaCl}$, $2 \mathrm{KCl}, 1.8 \mathrm{CaCl}_{2}$, and $4 \mathrm{Na}$-HEPES (pH 7.2-7.3). Acetylcholine chloride and $d$-tubocurarine chloride were obtained from Sigma Chemical.

\section{Results}

\section{Extracellular analysis}

Nicotinic transmission in normal Ringer. In bullfrog the preganglionic $\mathbf{B}$ and $\mathbf{C}$ pathways can be selectively activated through separate nerves (Libet et al., 1968; Horn and Stofer, 1988). Consequently, extracellular recording from postganglionic rami provides a simple means for systematically comparing nicotinic synapses on $\mathrm{B}$ and $\mathrm{C}$ neurons.

In $>30$ experiments, compound postganglionic $B$ and $C$ waves always followed trains of 40 presynaptic stimuli $(0.5-20$ $\mathrm{Hz}$ ) without appreciable changes in amplitude when recorded in normal Ringer (Figs. 1, 2). They consisted mainly of a compound action potential (CAP). In addition, the B wave contained a smaller compound nicotinic EPSP riding on the spike afterpotential. The constancy of the CAP indicates that the safety factor for nicotinic transmission normally remains high during repetitive stimulation in both cell systems.

d-Tubocurarine distinguishes between $B$ and $C$ cells. Ten micromolar dTC distinguished in two ways between nicotinic synapses on $\mathrm{B}$ and $\mathrm{C}$ cells during $5 \mathrm{~Hz}$ stimulation. It slightly reduced the first CAP and it revealed a strong use-dependent block in the B system. Figure 1 illustrates both effects. In this experiment dTC reduced the first B CAP by $2 \%$ and the first C CAP by $12 \%$. Though small, this difference was reproducible when dose-response curves were constructed (below). The difference during subsequent responses in the trains was more dramatic. $\mathrm{B}$ wave amplitude progressivcly declined during the train and reached a plateau at $36 \%$ of control (Fig. $1 A, B$ ). When summed over the entire train, average $\mathrm{B}$ wave amplitude was $54 \%$ of control (Fig. 1C). By contrast, $\mathrm{C}$ wave amplitude remained constant at $88 \%$ of control throughout the $5 \mathrm{~Hz}$ train. This suggests that dTC has two actions. Reduction of the first CAP in a train is independent of previous activity and is more sensitive to dTC in the $\mathrm{C}$ system than in the B system. Reduction of subsequent CAPs appears use dependent in the $\mathrm{B}$, but not the $\mathrm{C}$ system. When the entire $5 \mathrm{~Hz}$ trains are compared, the B system seems more sensitive to dTC than the $\mathrm{C}$ system. At this level, usedependent block of the $\mathrm{B}$ wave resembles the cumulative block of neuromuscular transmission seen during repetitive stimula- 
A
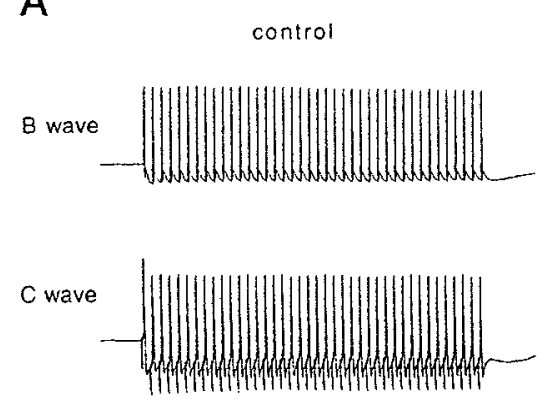

B

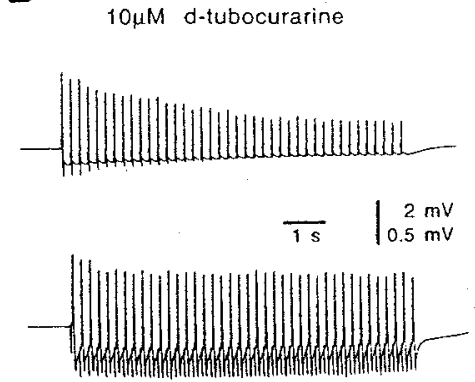

$\mathrm{C}$

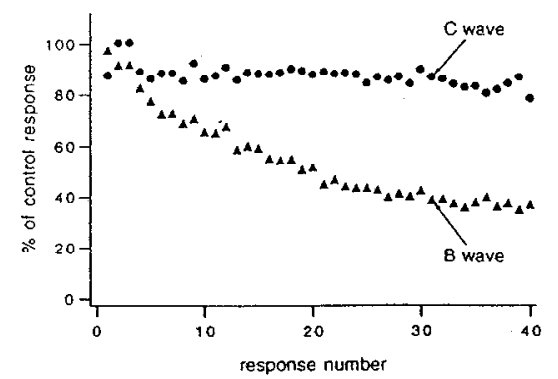

Figure 1. Selective antagonism of nicotinic transmission in the B system by $d$-tubocurarine (dTC). Postganglionic B and C waves $(A, B)$ were recorded extracellularly from rami communicantes. In control Ringer, the amplitudes of postganglionic responses remain constant during 40 pulse trains at $5 \mathrm{~Hz}(A)$. In $10 \mu \mathrm{M}$ dTC, a strong use-dependent block develops in the B system but not the C system $(B)$. CAP amplitudes in dTC are plotted $(C)$ as percentage of the corresponding control CAP for each pulse in the trains.

tion, a phenomenon also known as fade (Magleby et al., 1981; Gibb and Marshall, 1984). Unlike neuromuscular fade, which becomes strong at frequencies of $>50 \mathrm{~Hz}$ (Magleby et al., 1981), fade was clearly evident in the sympathetic B system during 0.5 $\mathrm{Hz}$ stimulation.

To establish the extent of fade in dTC, trains of CAPs were systematically recorded at six frequencies and five dTC concentrations. Standard trains of 40 stimuli were adopted because usedependent effects approximated steady-state values over the en-

A

control

$10 \mu \mathrm{M} \mathrm{dTC}$
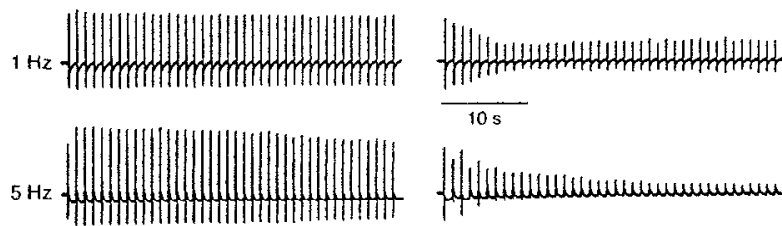

$10 \mathrm{~s}$
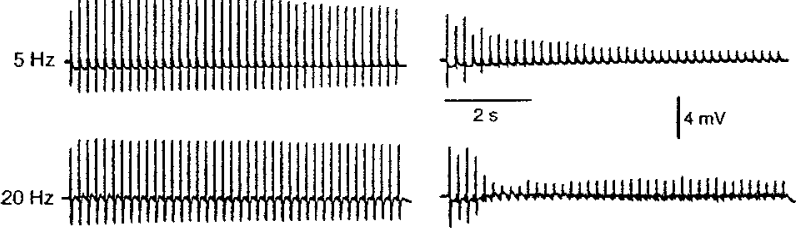

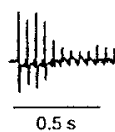

C

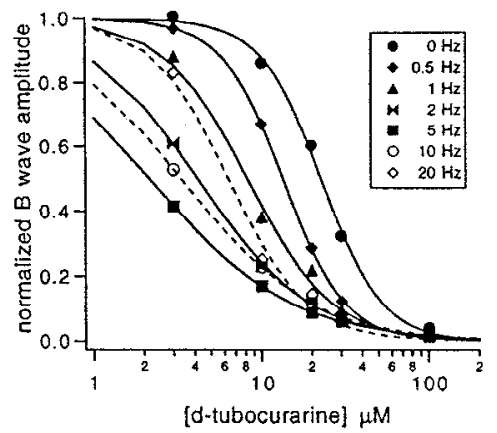

tire range of experimental conditions (Fig. 2). Paired observations of $\mathrm{B}$ and $\mathrm{C}$ waves were made to lessen variability between preparations (e.g., incomplete dissection of diffusion barriers). Figure 2 illustrates one of five experiments that yielded similar results. The amplitude of the first CAP in each train was taken as a measure of use-independent $(0 \mathrm{~Hz})$ block and the last CAP in each train was used to measure block at the associated frequency.

In the $B$ system, the extent of fade and its rate of onset in-
B

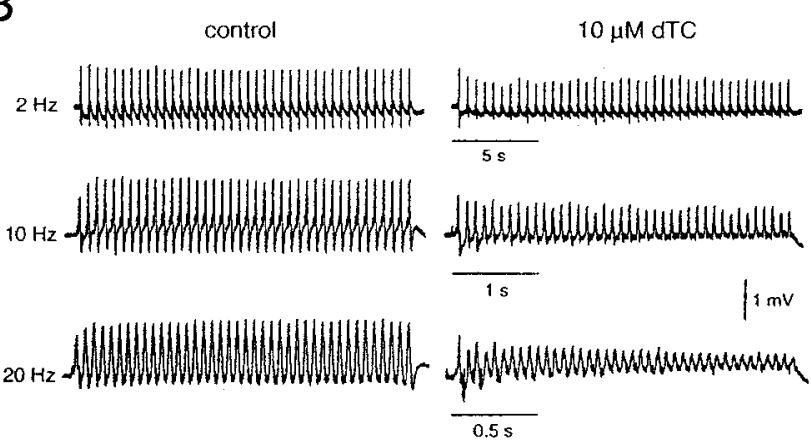

$E$

Figure 2. Frequency dependence of dose-response relations for dTC. In control recordings of postganglionic CAPs in normal Ringer, transmission remains constant throughout trains at all frequencies in the $\mathrm{B}(A)$ and $\mathrm{C}(B)$ systems. In $10 \mu \mathrm{M}$ dTC $(A, B)$ fade is present at all frequencies in the B system but only at 10 and $20 \mathrm{~Hz}$ in the $\mathrm{C}$ system. This is evident in dose-response curves for each frequency in the B system $(C)$ and $C$ system $(D)$. The $0 \mathrm{~Hz}$ curves were constructed from measurements of the first CAP in trains and the other curves were based on the last CAP in trains. Responses in dTC were normalized to their corresponding controls in normal Ringer. In the B system $(C)$, there is a progressive leftward shift of the dose-response relations between 0 and $5 \mathrm{~Hz}$ (solid symbols and lines). Above $5 \mathrm{~Hz}$ (open symbols and dotted lines) the curves shift back to the right. In the $\mathrm{C}$ system $(D)$ the dose-response relations were shifted only at 10 and $20 \mathrm{~Hz}$. A plot of $\mathrm{IC}_{50}(\mathrm{mean} \pm \mathrm{SD}$ ) versus stimulus frequency (E) using data from five paired experiments shows how the two cell systems differ $(*, p<0.05)$. 
Figure 3. Differential recovery from fade of the extracellular $\mathrm{B}$ wave $(A)$ and $C$ wave $(B)$ after $20 \mathrm{~Hz}$ stimulation in dTC. Trace $A$ was recorded in $10 \mu \mathrm{M}$ dTC and trace $B$ was recorded in 20 $\mu \mathrm{M}$ dTC. After each train of 40 stimuli, four single responses were evoked at 8 sec intervals. The dotted line in each panel marks the amplitude of the first CAP in the train.

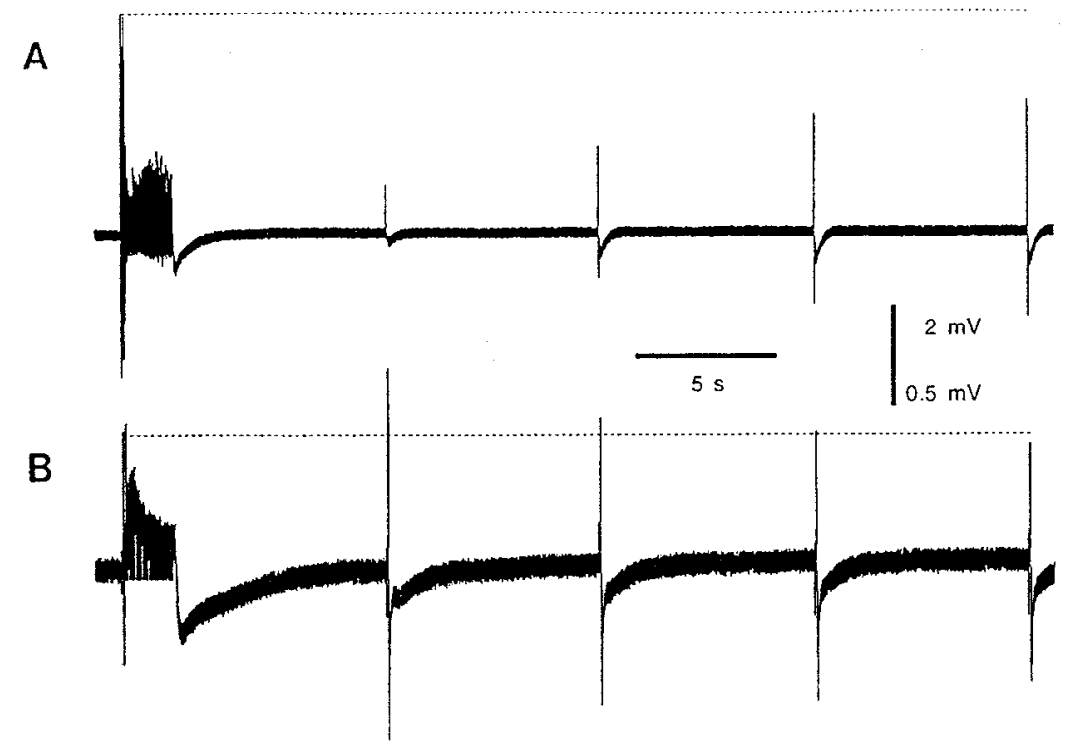

creased with stimulus frequency (Fig. $2 A$ ). When dose-response curves were constructed from the data at each frequency (Fig. $2 C$ ), fade was manifest as a frequency-dependent leftward shift in the dose-response relation for dTC. The decrease in $\mathrm{IC}_{50}$ was largest between 0 and $2 \mathrm{~Hz}$ and approached 10-fold on reaching its full extent at $5 \mathrm{~Hz}$. At frequencies of $>5 \mathrm{~Hz}$ there was a slight increase in the $\mathrm{IC}_{50}$ for $\mathrm{dTC}$.

The same analysis demonstrated fade in the $\mathrm{C}$ system but at higher frequencies (Fig. $2 B$ ). Between 0 and $5 \mathrm{~Hz}$, there was no frequency-dependent shift in the dose-response curve for dTC, but the $\mathrm{IC}_{50}$ was progressively reduced at 10 and $20 \mathrm{~Hz}$ (Fig. 2D).

Comparison of the $\mathrm{IC}_{50}$ versus frequency data from five experiments illustrates the differential effects of dTC (Fig. 2E). At $0 \mathrm{~Hz}$, the $\mathrm{C}$ system was 2.1 times more sensitive to dTC than the B system $(p<0.05)$. This relation reversed at 2 and $5 \mathrm{~Hz}$ with the B wave being 2.2 and 2.9 times more sensitive to dTC than the $\mathrm{C}$ wave. At $20 \mathrm{~Hz}$ the $\mathrm{C}$ wave was again more sensitive to dTC. These observations demonstrate a complex relationship between stimulus frequency and curariform block of nicotinic synapses on B and C neurons. Regardless of the underlying mechanisms the data show that block can be selective for either cell type depending on the stimulus frequency and the dose of dTC.

In addition to its effects during trains, dTC unmasked a third cell-specific effect during recovery after trains. Recoveries were measured by recording four to eight CAPs at $0.125 \mathrm{~Hz}$ after conditioning trains of 40 stimuli at frequencies that produce fade (Fig. 3). In normal Ringer, the amplitudes of $B$ and $C$ waves during the recovery period remained unchanged. However, consistently different recovery profiles were observed in dTC. Recovery in the B system was characterized by posttrain depression of CAP amplitude that lasted about a minute (Fig. $3 A$ ), and recovery in the $\mathrm{C}$ system was characterized by posttrain potentiation of CAP amplitude that persisted for tens of seconds (Fig. $3 B)$.

\section{Intracellular analysis}

Use-dependent block of nicotinic synapses in dTC could arise from multiple mechanisms that progressively reduce EPSP size during trains (see introductory remarks). We made intracellular recordings to resolve the possibilities and determine whether dTC discriminates between nicotinic receptors on the two cell types.

Effects of repetitive stimulation on EPSP amplitude. Initial recordings were made under current clamp because it produces less impalement damage than voltage clamp and we wanted to observe effects of dTC on firing, a condition that parallels the extracellular recordings.

In both cell types, nicotinic EPSPs remained suprathreshold during trains $(0.5-20 \mathrm{~Hz})$ recorded in normal Ringer from cells having input resistances of $>50 \mathrm{M} \Omega$ In poorer recordings $\left(R_{\text {input }}\right.$ $<20 \mathrm{M} \Omega$ ), firing sometimes was blocked by hyperpolarizing the resting potential. Although EPSP amplitude appeared to fade, these measurements were deemed unreliable because of small amplitude axonal spikes conducting passively into the soma.

In 10-30 $\mathrm{M}$ dTC, subthreshold EPSPs became clearly evident during repetitive stimulation (Fig. 4). We compared this effect with the extracellular results.

In $B$ cells, low-frequency stimulation $(1-5 \mathrm{~Hz})$ caused fade of intracellular EPSP amplitude. Figure $4 A$ illustrates a cell stimulated at $5 \mathrm{~Hz}$ in $20 \mu \mathrm{M}$ dTC. The first EPSP in the train was subthreshold. The next 15 EPSPs all triggered action potentials and then the EPSP became subthreshold during 21 of 24 subsequent responses. After the train, EPSP amplitude remained low and did not reach threshold again until after $20 \mathrm{sec}$ of recovery. This mirrored the time course of fade and of poststimulus depression in extracellular records (Figs. 1B, 3A). An additional feature, not seen extracellularly, was the slow muscarinic EPSP during the train (Libet et al., 1968). Fade and poststimulus depression were also seen in cells without demonstrable muscarinic EPSPs.

In $C$ cells, by contrast, low-frequency stimulation $(1-5 \mathrm{~Hz})$ in dTC commonly caused an increase in EPSP amplitude (Fig. 4C). Fade only became evident at 10 and $20 \mathrm{~Hz}$. Figure $4 B$ illustrates a $C$ cell stimulated at $20 \mathrm{~Hz}$. In this case the first seven EPSPs were suprathreshold and fade became evident during subsequent responses. Although four EPSPs during the latter part of the train exceeded threshold, there was an overall progressive decline in EPSP amplitude. After the train, EPSP amplitude remained elevated above threshold. This behavior is consistent with fade and posttetanic potentiation in extracellular records (Figs. 2, 3). 

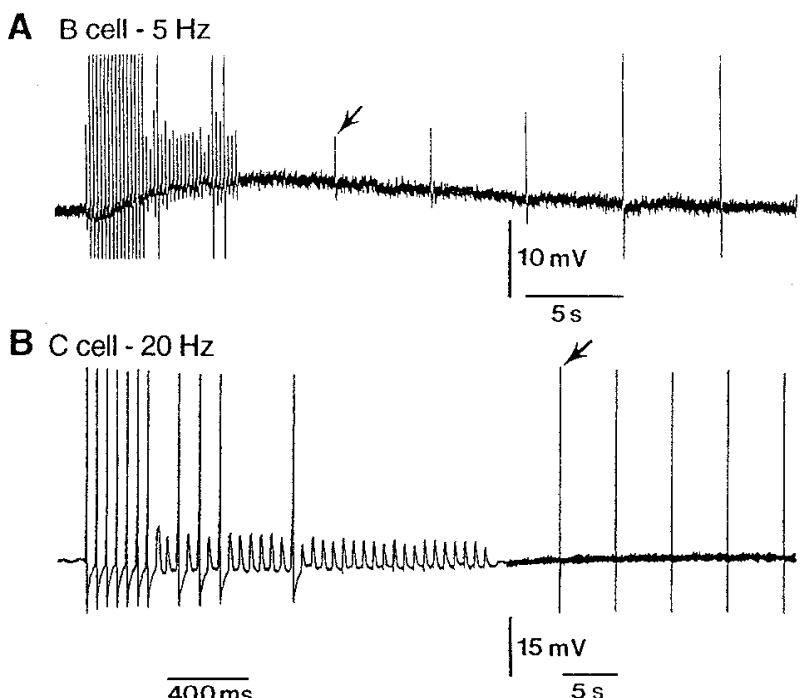

C C cell $-2 \mathrm{~Hz}$

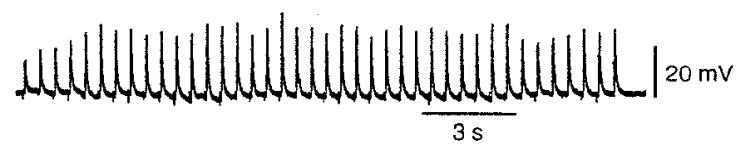

Figure 4. Intracellular recordings of synaptic responses under current clamp in $20 \mu \mathrm{M}$ dTC. Stimulation of a B cell $(A)$ at $5 \mathrm{~Hz}$ and a $\mathrm{C}$ cell (B) at $20 \mathrm{~Hz}$ both producc fadc. Arrows in each panel mark posttrain depression in the $B$ cell and potentiation in the $C$ cell. A train of EPSPs in another $C$ cell $(C)$ undergoes potentiation during repetitive stimulation at $2 \mathrm{~Hz}\left(V_{m}=-90 \mathrm{mV}\right)$. A shows a chart record in which the larger responses are truncated action potentials $\left(V_{m}=-60 \mathrm{mV}\right)$. The slow depolarization is a muscarinic EPSP. $B$ is a digitized record printed at two speeds demarcated by a change in baseline thickness $\left(V_{m}=-52\right.$ $\mathrm{mV})$.
Preganglionic $\mathrm{C}$ stimulation elicited a slow peptidergic EPSP (Jan and Jan, 1982) in some but not all of our recordings. Generally the slow EPSP began with a latency that was longer than the duration of the 10 and $20 \mathrm{~Hz}$ trains where fade occurs.

Comparison of EPSPs with responses to iontophoretically applied ACh. At the neuromuscular junction, focal application of $\mathrm{ACh}$ has been used to infer the site of fade (Magleby et al., 1981; Gibb and Marshall, 1984). Following a similar approach we measured the amplitudes of repetitive responses to ACh applied by brief $(5-15 \mathrm{msec})$ current pulses and compared them with changes in EPSP amplitude. The briefest $\mathrm{ACh}$ responses in our best experiments were still three to five times slower than EPSPs. To avoid fusion between successive $\mathrm{ACh}$ responses and desensitization we used frequencies of $\leq 5 \mathrm{~Hz}$.

Figure $5 A$ illustrates interdigitated synaptic and iontophoretic responses from a $B$ cell stimulated at $2 \mathrm{~Hz}$ in $20 \mu \mathrm{M}$ dTC. EPSP amplitude declined during the train while the ACh response held constant. This indicates fade is presynaptic. Similar results were seen during trains containing only EPSPs or iontophoretic responses. This shows the result is not caused by interaction between the responses. When $\mathrm{C}$ cells were studied in a similar manner EPSP amplitude grew during 1-2 Hz stimulation (Figs. $4 C, 5 B$ ), while $A C h$ responses held constant or slightly declined (Fig. $5 B, D$ ). Thus, potentiation of EPSPs at low frequencies in C cells is presynaptic.

During posttrain recovery periods, $\mathrm{ACh}$ responses were sometimes enhanced during slow EPSPs. In B cells, where the nicotinic EPSP remains depressed after $20 \mathrm{~Hz}$ stimulation, this implies that recovery is characterized by residually reduced transmitter release. The results were more complex in $C$ cells where $\mathrm{ACh}$ responses and nicotinic EPSPs were both potentiated after trains at $20 \mathrm{~Hz}$. However, potentiation of the EPSP often preceded by $5-15 \mathrm{sec}$ that of the ACh response. This suggests posttetanic potentiation of release in $\mathrm{C}$ cells.

$d T C$ is a competitive antagonist of nicotinic receptors on $B$ and $C$ neurons. An independent approach for testing the possible
A
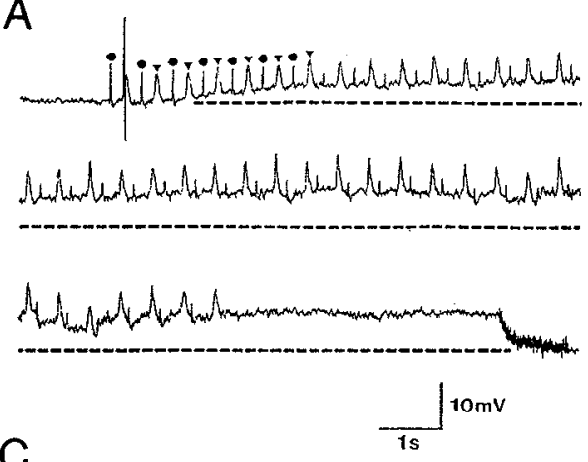

C

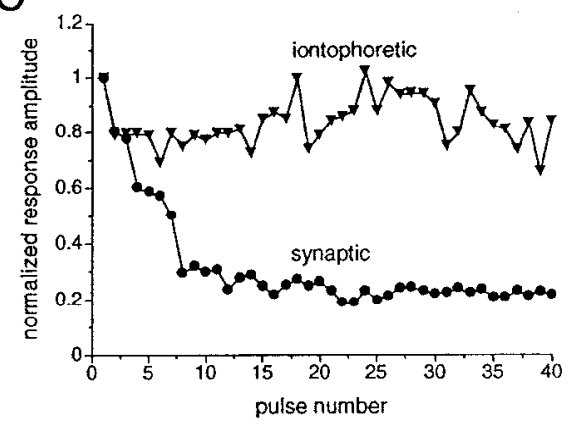

B

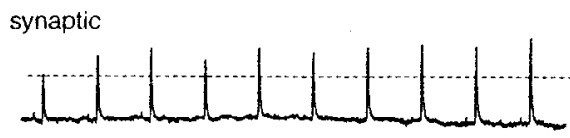

iontophoretic

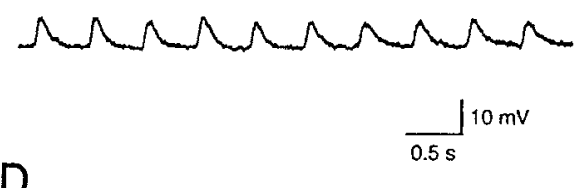

$\mathrm{D}$

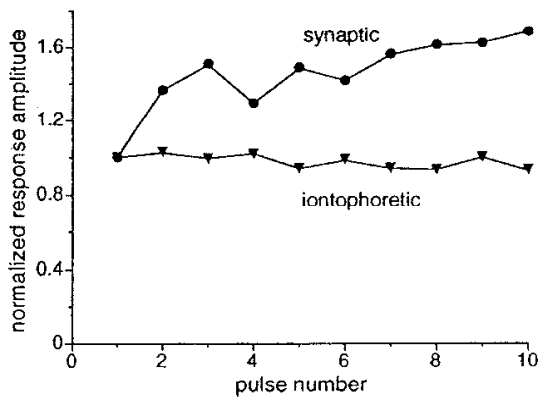

Figure 5. Comparison of synaptic potentials with iontophoretic responses to $\mathrm{ACh}$ in a $\mathrm{B}$ cell $(A, C)$ and a $\mathrm{C}$ cell $(B$, $D$ ) in $20 \mu \mathrm{M}$ dTC. In $A$, alternating synaptic potentials $(O)$ and $A C h$ responses ( $\nabla)$ were recorded at $2 \mathrm{~Hz}$ from a $\mathrm{B}$ cell $\left(V_{m}=-48 \mathrm{mV}\right)$. The thickened baseline at the end of the trace was recorded at a slower speed and shows recovery from slow muscarinic depolarization. A plot of the response amplitudes $(C)$ shows that EPSPs faded while the iontophoretic responses remained constant. In $B$, trains of 10 EPSPs and $10 \mathrm{ACh}$ responses were sequentially recorded at $2 \mathrm{~Hz}$ from a C cell $\left(V_{m}=-15 \mathrm{mV}\right)$. A plot of the response amplitudes $(D)$, normalized to the first one in each train, shows that the first few EPSPs grew and then remained elevated, but that iontophoretic responses remained constant in amplitude. 

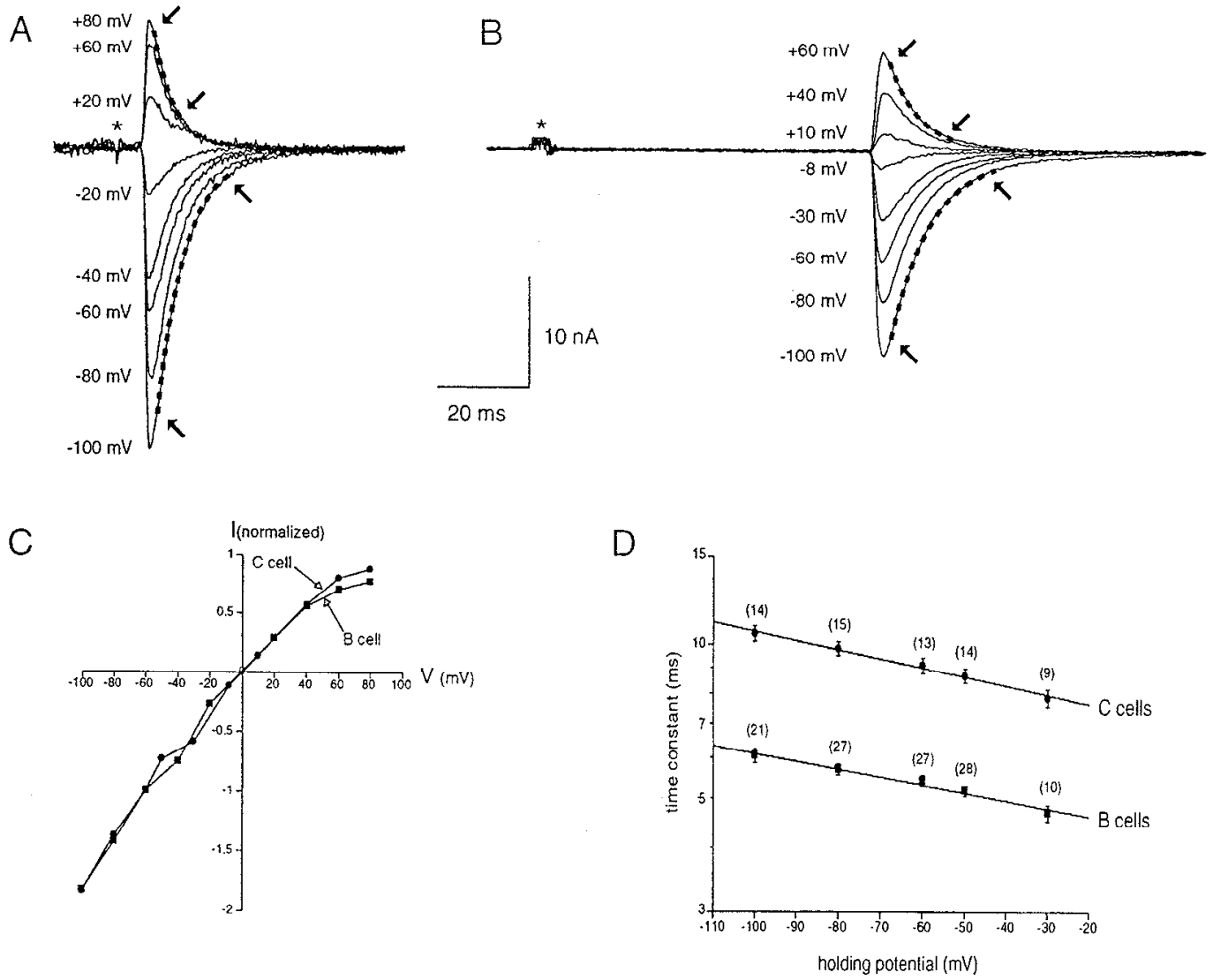

Figure 6. Voltage dependence of the nicotinic EPSC. Families of synaptic currents in a B neuron $(A)$ and a C neuron $(B)$ are averages of five records. Each trace is labeled with the corresponding holding potential. Stimulus artifacts are marked $(*)$. The decay phase of each synaptic current was fit to a single exponential between $90 \%$ and $10 \%$ of peak values (arrows in $A$ and $B$ ). Examples of curve fits are superimposed as dashed lines at positive and negative extremes of the voltage range $(A, B)$. Peak synaptic currents were normalized to their values at $-60 \mathrm{mV}$ and plotted against the holding potential $(C)$. Plots of time constants (mean $\pm \mathrm{SE}$ ) versus holding potential $(D)$ contain data from $28 \mathrm{~B}$ cells and $15 \mathrm{C}$ cells and were fit to the equation $\tau(V)=\tau_{0} e^{A V}$ (solid lines).

postsynaptic origin of fade was to examine dTC's blocking mechanism by measuring synaptic currents. Time constants $(\tau)$ of decay for fast synaptic currents provide a measure of mean open-channel lifetime (Magleby and Stevens, 1972a,b) and a test for distinguishing competitive from open-channel block by dTC (Ascher et al., 1979; Rang, 1982). In these experiments we only analyzed cells innervated by a single primary presynaptic fiber.

Control EPSCs were recorded in normal Ringer at different holding potentials (Fig. $6 A, B$ ) and used to construct $I-V$ curves (Fig. $6 C$ ) for nicotinic currents and to measure the voltage dependence of $\tau$ (Fig. $6 D$ ). At negative potentials the $I-V$ relations were linear. Based on the slope, peak synaptic conductance was $226 \pm 59 \mathrm{nS}$ in $28 \mathrm{~B}$ cells (mean $\pm \mathrm{SD}$ ) and $163 \pm 53 \mathrm{nS}$ in $15 \mathrm{C}$ cells $(p<0.001)$. Linear regression analysis of the data showed the reversal potential of the EPSC was $-7 \mathrm{mV}$ in B neurons and $-5 \mathrm{mV}$ in $\mathrm{C}$ neurons. Currents were also measured at positive potentials in a few cells. The $I-V$ relations show inward rectification at potentials positive to $+40 \mathrm{mV}$ (Fig. $6 \mathrm{C}$ ). Decay of the EPSC from $90 \%$ to $10 \%$ of peak amplitude was best fit by a single exponential of the form $I(t)=I_{0} e^{-t \tau}$, where $I$ is the amplitude of the current at times $t$ and 0 (Fig. 6A,B). As expected, $\tau$ differed between the cell types. At $-50 \mathrm{mV}, \tau$ was $5.16 \pm 0.60 \mathrm{msec}$ (mean $\pm \mathrm{SD}$ ) in $28 \mathrm{~B}$ neurons and $8.69 \pm$ $1.09 \mathrm{msec}$ in $15 \mathrm{C}$ neurons $(p<0.0001)$. When $\tau$ was plotted against voltage ( $V$ ) (Fig. $6 D$ ), the data were well fit by the equation $\tau(V)=\tau_{0} e^{A V}$, where $\tau_{0}$ is the value of $\tau$ at $0 \mathrm{mV}$ and $A$ is the coefficient of voltage dependence. $A$ was $-0.0033 \pm 0.0012$ $\mathrm{mV}^{-1}$ (mean $\pm \mathrm{SD}$ ) in $28 \mathrm{~B}$ cells and $-0.0039 \pm 0.0011 \mathrm{mV}^{-1}$ in $15 \mathrm{C}$ cells $(p>0.1)$.

EPSCs in both cell types were similariy affected by dTC. Three $\mu \mathrm{M}$ dTC reduced EPSC amplitude without altering its time course (Fig. $7 A, D$ ). In $I-V$ plots (Fig. $7 B, E$ ) $3 \mu \mathrm{M}$ dTC had no effect on the extrapolated reversal potential $(-4 \mathrm{mV}$ in $\mathrm{B}$ and $C$ cells) and reduced synaptic conductance to $46 \pm 9 \%$ of control (mean \pm SD) in six B cells and $46 \pm 12 \%$ of control in four $\mathrm{C}$ cells $(P>0.9)$. There was no sign of voltage-dependent block judging from the fact that the $I-V$ relations remained linear at negative potentials in dTC (Ascher et al., 1979). This is further supported by the finding that 3-10 $\mu \mathrm{M}$ dTC had no effect on $\tau$ between -30 and $-100 \mathrm{mV}$ in nine B cells (Fig. 7C) and six $\mathrm{C}$ cells (Fig. $7 F$ ).

Evidence against presynaptic nicotinic receptors and cumulative open-channel block of postsynaptic receptors. Previous studies have reported presynaptic nicotinic receptors in frog sympathetic ganglia (Koketsu and Nishi, 1968; Ginsborg, 1971). If such receptors modulate $\mathrm{ACh}$ release, then $\mathrm{dTC}$ would be expected to alter the rate of change in EPSC amplitude during repetitive stimulation (Magleby et al., 1981; Gibb and Marshall, 1984). Alternatively, a low level of open-channel block during a single response might accumulate during repetitive activity (Gurney and Rang, 1984). We examined these possibilities by 
A

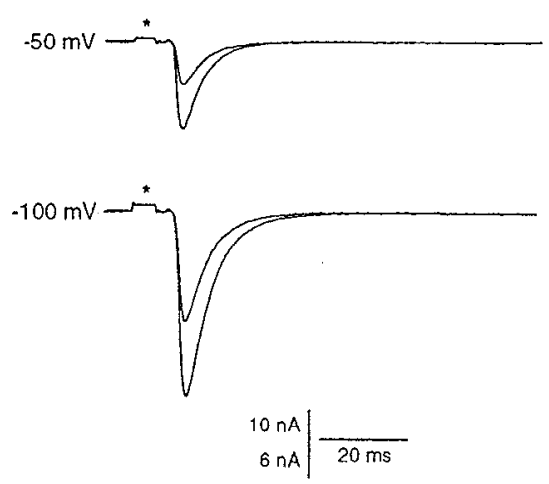

D

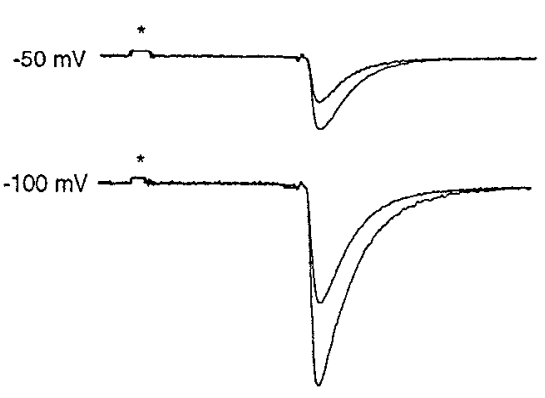

B

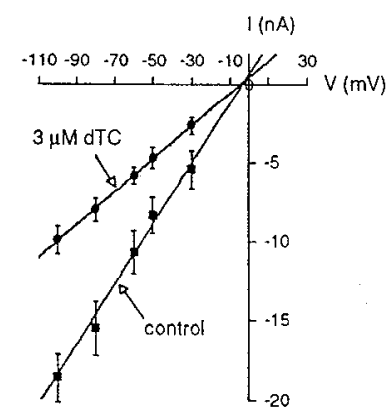

$\mathrm{E}$

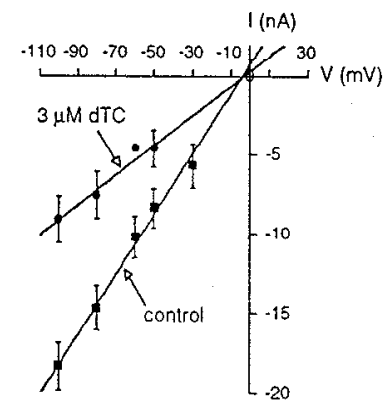

C

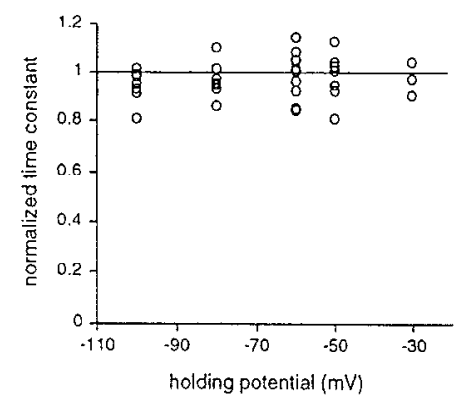

F

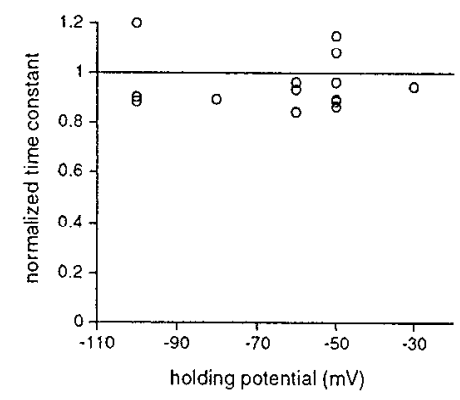

Figure 7. Competitive block of EPSCs by dTC in B cells $(A-C)$ and C cells $(D-F)$. EPSCs $(A, D)$ were recorded in control Ringer $($ larger currents in each pair) and in $3 \mu \mathrm{M} \mathrm{dTC} \mathrm{over} \mathrm{a} \mathrm{range} \mathrm{of} \mathrm{holding} \mathrm{potentials.} \mathrm{The} I-V$ relations in $B$ and $E$ contain paired observations in control Ringer and dTC from six B cells and four $C$ cells. In $C$ and $F$, time constants for EPSC decay in dTC were normalized to their control values in Ringer and plotted against the holding potentials. $C$ contains data from six B neurons in $3 \mu \mathrm{M}$ dTC and three B neurons in $10 \mu \mathrm{M}$ dTC. $F$ contains data from four $C$ neurons in $3 \mu \mathrm{M}$ dTC and two $C$ neurons in $10 \mu \mathrm{M}$ dTC.

first determining the effect of repetitive stimulation on EPSC. amplitude.

In normal Ringer, repetitive stimulation had different effects on EPSC amplitude in B and C cells. Low-frequency trains were dominated by depression in $\mathrm{B}$ cells and potentiation in $\mathrm{C}$ cells. Figure $8, A$ and $C$, illustrates a $\mathrm{B}$ cell in which there was slight depression during a $1 \mathrm{~Hz}$ train. The pattern became biphasic during $5 \mathrm{~Hz}$ stimulation. Initial potentiation of the EPSC was followed by depression below the amplitude of the first response. At 10 and $20 \mathrm{~Hz}$ the transient potentiation grew larger and the amplitude of the last EPSC in each train remained elevated. Frequency-dependent changes in EPSC amplitude were different in $\mathrm{C}$ cells (Fig. $8 B, D$ ). During $5 \mathrm{~Hz}$ stimulation, the first few EPSCs potentiated and then remained elevated throughout the train. At $10 \mathrm{~Hz}$ there was less potentiation and, at 20 $\mathrm{Hz}$, transient potentiation gave way to clear depression. These effects parallel the frequency dependence of curariform block in extracellular records (Fig. 2) and changes in EPSP amplitude seen in dTC under current clamp (Figs. 4, 5).

Hypothetical roles for presynaptic nicotinic receptors and $\mathrm{cu}-$ mulative postsynaptic open-channel block were tested by measuring the effects of $10 \mu \mathrm{M}$ dTC on trains of EPSCs in B neurons (Fig. 9). At $-50 \mathrm{mV}$, dTC uniformly reduced the amplitudes of all EPSCs in a $5 \mathrm{~Hz}, 40$ pulse train, and increasing the holding potential to $-100 \mathrm{mV}$ uniformly restored EPSC amplitudes (Fig. $9 A$ ). When data from 11 neurons were normalized to the first response in each train and averaged, there was no effect of dTC on either the initial rate of transient potentiation or the subsequent rate of fade during the train (Fig. 9B). In four cells where trains were recorded at -50 and $-100 \mathrm{mV}$, hyperpolarization had no effect on the time course of potentiation and fade (Fig. $9 C$ ). There was no effect of dTC on $\tau$ for EPSC decay during the train at either membrane potential (Fig. $9 D, E$ ).

It was impractical to measure the effect of $\mathrm{dTC}$ on the rate of fade in $\mathrm{C}$ neurons. Instead we looked to see whether presynaptic nicotinic receptors on $\mathrm{C}$ fibers could alter the evoked release of luteinizing hormone-releasing hormone (LHRH). In addition to causing fade, $20 \mathrm{~Hz}$ stimulation is optimal for evoking LHRH release and this is reflected in the amplitude of the slow EPSP (Peng and Horn, 1991). Moreover, peptidergic EPSPs that are free of nicotinic EPSPs can be recorded from B neurons (Jan and Jan, 1982). In five of five B cells, $100 \mu \mathrm{M}$ dTC had no effect on the peptidergic EPSP evoked by 100 stimuli at $20 \mathrm{~Hz}$ (Fig. 10). It remained at $102 \pm 12 \%$ of control amplitude.

\section{Discussion}

The extracellular results show dTC can selectively block nicotinic synapses on $\mathrm{B}$ or $\mathrm{C}$ neurons depending on the dose and stimulus parameters. The intracellular data indicate dTC is a competitive antagonist and does not select between postsynaptic. receptors on the two cell types. Instead, dTC acts indirectly to unmask a difference in $A C h$ release by preganglionic $B$ and $C$ neurons that is evident at low frequencies of stimulation. Presynaptic nicotinic receptors do not modulate $\mathrm{ACh}$ release under conditions that produce fade in the B system and do not modulate $\mathrm{LHRH}$ release under conditions that produce fade in the $\mathrm{C}$ system. Comparison of extracellular and intracellular data per- 


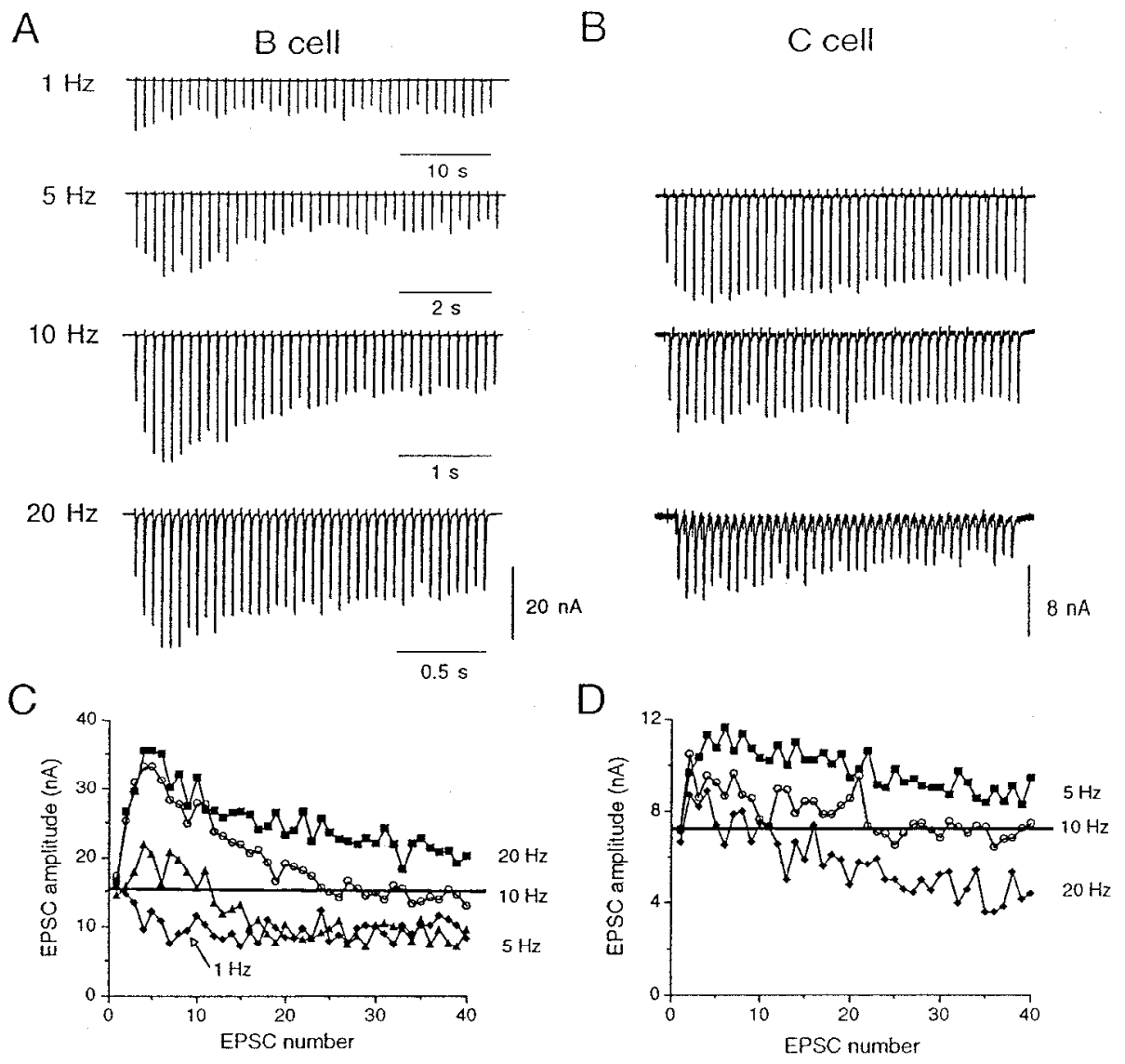

Figure 8. Repetitive trains of 40 EPSCs in normal Ringer are characterized by frequency-dependent changes in amplitude in a $\mathrm{B}$ neuron $(A)$ and a $C$ neuron $(B)$. Amplitudes of individual EPSCs are plotted in $C$ and $D$. Horizontal lines mark the amplitudes of the first responses in each train.

$$
\text { A }
$$

mits an estimate of the safety factor for nicotinic transmission in cells unperturbed by electrode damage or d' $\mathrm{I} C$.

\section{Nicotinic receptors on $B$ and $C$ neurons are similar but not identical}

Our data extend previous studies of nicotinic receptors in bullfrog ganglia and permit a more detailed comparison between cell types. The synaptic conductances in $\mathrm{B}$ and $\mathrm{C}$ cells differ in their kinetics and size, but are indistinguishable in terms of their reversal potentials, voltage sensitivity, and block by dTC. On average, $\tau$ is $\sim 70 \%$ slower in $\mathrm{C}$ cells, and peak synaptic conductance is $\sim 40 \%$ larger in B cells. Consequently, the total charge entering $C$ cells is $-33 \%$ larger than that cntering $B$ cells ( 59 vs $43 \mathrm{pC}$ ).

In the original description of $\mathrm{B}$ and $\mathrm{C}$ cells in toad sympathetic ganglia, Nishi et al. (1965) demonstrated reversal of the EPSP at 0 to $-10 \mathrm{mV}$, and inward rectification at positive potentials. Subsequent voltage-clamp studies in B neurons confirmed that synaptic currents behave like EPSPs (Kuba and Nishi, 1979; MacDermott et al., 1980; Comnor et al., 1983). We observed similar behavior of synaptic currents in C cells (Fig. 6). Our estimates of $\tau$ agree with earlier reports for B cells (Kuba and Nishi, 1979; MacDermott et al., 1980) and are slightly smaller than values reported for C cells (Marshall, 1986). Our data provide the first evidence for similar voltage dependence (A) of $\tau$ in the two cell types. Although $\tau$ may reflect mean channel open time (Magleby and Stevens, 1972a,b), the situation is probably more complex given single channel studies of rat sympathetic neurons that show $\tau$ reflects burst duration rather than individual channel openings (Derkach et al., 1987; Mathie et al., 1987, 1991). The difference between $\tau$ in $B$ and $C$ cells remains unexplained.

\section{Estimating the safety factor for nicotinic transmission}

In normal Ringer, CAP amplitude remains stable during repetitive stimulation (Figs. 1, 2), thereby showing that the safety factor for nicotinic transmission is high in both cell systems. The size of the safety factor can be estimated by comparing the extracellular and intracellular data. In extracellular experiments, the $\mathrm{IC}_{50}$ reflects the concentration of $\mathrm{dTC}$ that reduces EPSP amplitude so that it is subthreshold in half the neurons. At $0 \mathrm{~Hz}$, the $\mathrm{IC}_{50}$ was $27.9 \mu \mathrm{M}$ in the $\mathrm{B}$ system and $13.5 \mu \mathrm{M}$ in the $\mathrm{C}$ system (Fig. 2E). By contrast, only $3 \mu \mathrm{M}$ dTC was needed to block approximately half the synaptic current in both cell types. Therefore, more than half the receptors must be blocked to reduce EPSP amplitude below threshold. The safety factor in B cells can be further defined because fade is presynaptic. Five hertz stimulation depresses EPSC amplitude by $\sim 20 \%$ (Fig. 9B) and shifts the extracellular $\mathrm{IC}_{50}$ for dTC to $4.8 \mu \mathrm{M}$ (Fig. $2 E$ ), just slightly greater than $3 \mu \mathrm{M}$, which blocks half the current. This means that $<40 \%$ of the synaptic conductance is required to bring half the $\mathrm{B}$ neurons to threshold in the absence of drugs or cellular damage. The twofold difference in extracellular $\mathrm{IC}_{50}$ values implies that the safety factor for transmission is lower in $\mathrm{C}$ cells and conforms with the finding that synaptic conductance is smaller in $\mathrm{C}$ cells. We conclude the safety factor is $>2.5$ in the B system and somewhat smaller in the C system. 
A
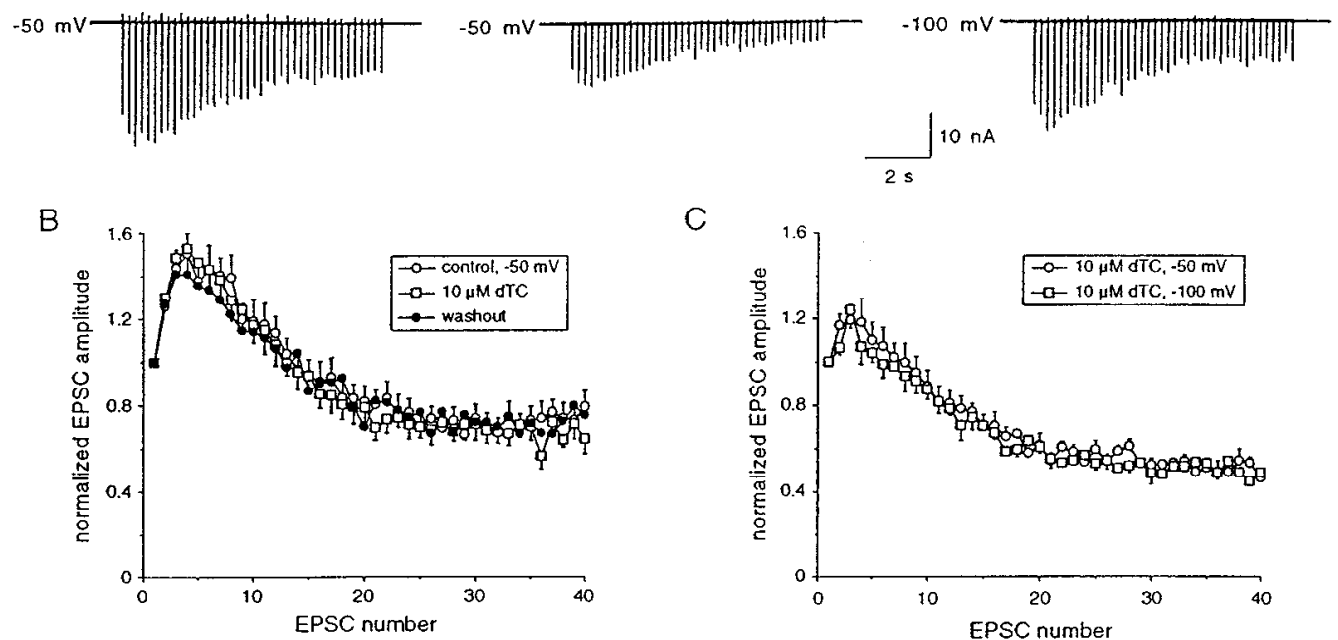

C
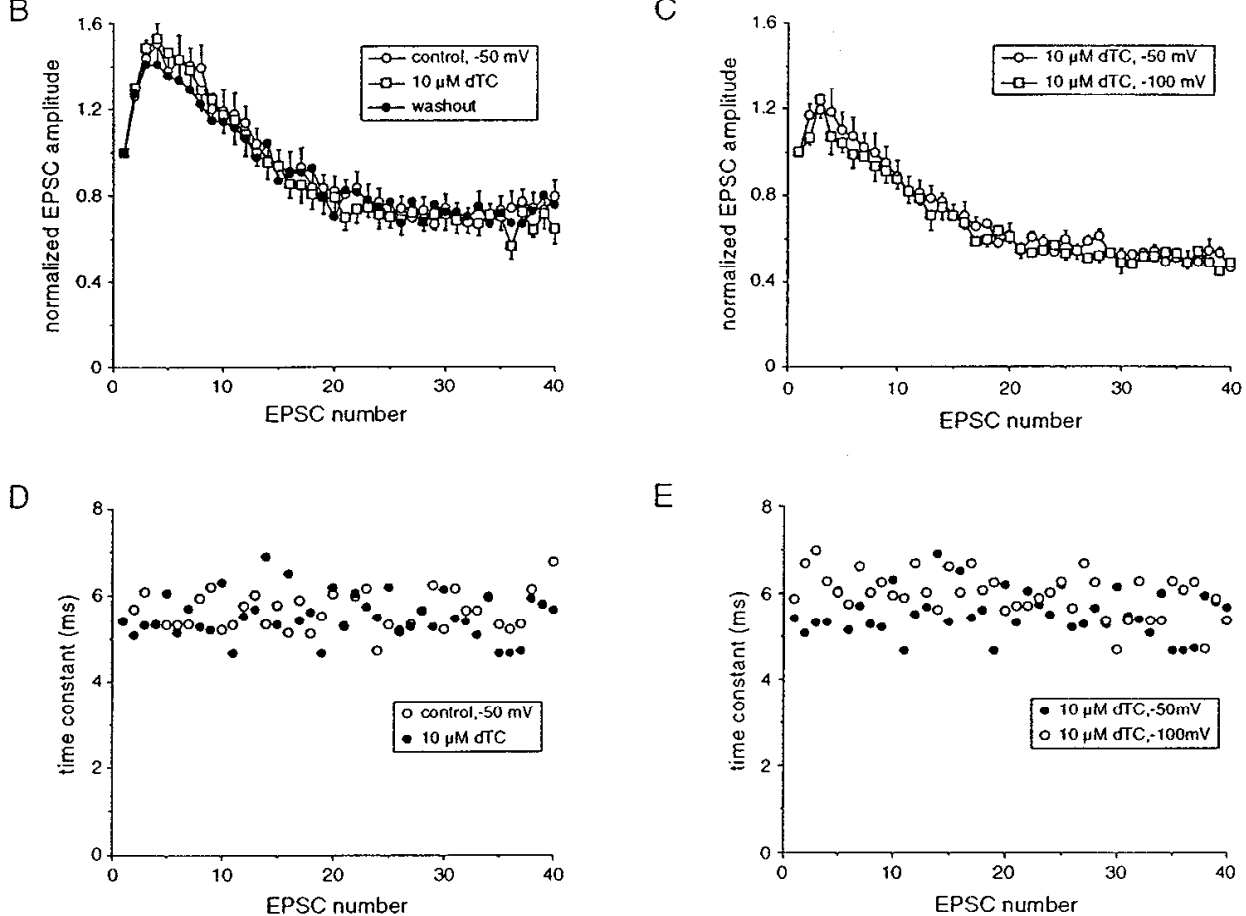

Figure 9. The effect of $10 \mu \mathrm{M}$ dTC on EPSCs in B cells during $5 \mathrm{~Hz}$ trains. Records from one cell $(A)$ show that dTC reduced synaptic currents throughout the train. When the driving force on the currents was roughly doubled by increasing the holding potential from -50 to $-100 \mathrm{mV}$, the EPSCs were nearly restored to their original amplitudes. Paired data from 11 cells also show the effect of dTC on EPSC amplitude at $-50 \mathrm{mV}$ was uniform throughout the train $(B)$. EPSC amplitudes were normalized to the first response in each train and plotted as the mean \pm SE. The washout data represent four cells in the group and do not contain error bars. In $C$, paired data from four cells show that hyperpolarization from -50 to $-100 \mathrm{mV}$ did not alter the rate of fade. In $D$ and $E, \tau$ values during trains are plotted (data from the neuron in $A$ ). At $-50 \mathrm{mV}$, dTC had no effect on $\tau$, which remained constant during the train $(D)$. When $V_{m}$ was shifted from -50 to $-100 \mathrm{mV}$ in dTC $(E)$, $\tau$ increased, but held constant during both trains.

\section{Comparison with nicotinic receptors on other autonomic neurons}

In the rat submandibular ganglion, dTC is primarily an openchannel blocker (Ascher et al., 1979; Rang, 1982), while in bullfrog sympathetic $B$ and $C$ neurons $\mathrm{dTC}$ is a competitive antag- onist (Lipscombe and Rang, 1988; present results). Does this reflect differences between frog and rat or differences between sympathetic and parasympathetic neurons? Both factors may be relevant. In rabbit sympathetic neurons dTC is primarily a competitive inhibitor positive to $-80 \mathrm{mV}$, whereas in rat sympathetic

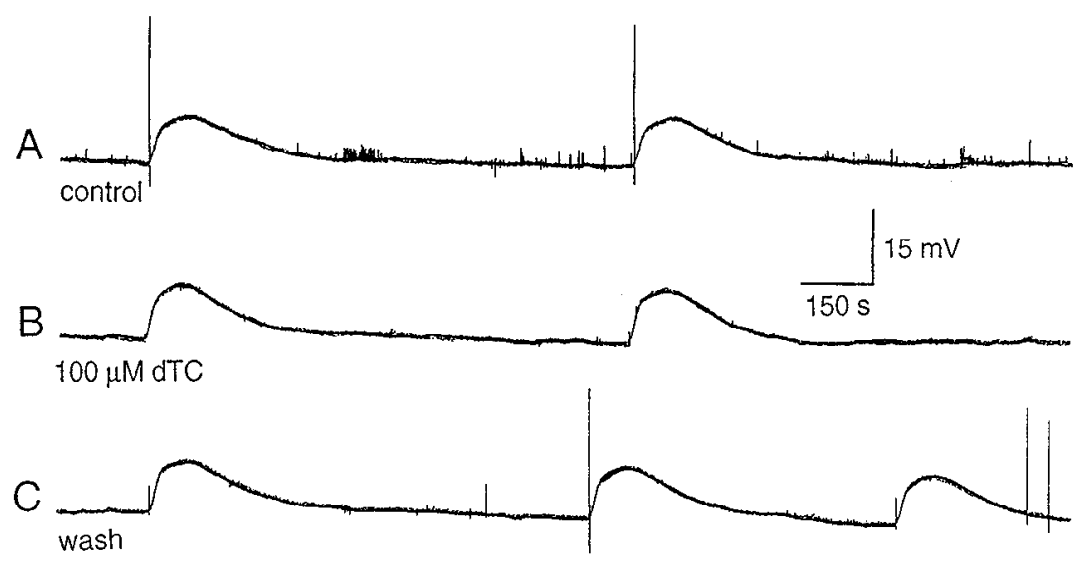

Figure 10. The slow peptidergic EPSP recorded from a $B$ neuron is insensitive to dTC. Under current clamp $\left(V_{m}=-45 \mathrm{mV}\right)$, peptidergic EPSPs were evoked by 100 shock trains at 20 $\mathrm{Hz}$. to the preganglionic $\mathrm{C}$ pathway. The responses recorded in control Ringer $(A)$, in $100 \mu \mathrm{M}$ dTC $(B)$, and after washout in normal Ringer $(C)$ were indistinguishable. 
neurons, dTC is primarily an open-channel hlocker (Skok et al., 1989).

\section{dTC unmasks differences in ACh release by preganglionic $B$ and $C$ terminals}

Iontophoresis experiments (Fig. 5) showed that altered postsynaptic sensitivity can not account for the changes in EPSP amplitude during low-frequency stimulation. The behavior of EPSCs in normal Ringer (Fig. 8) is also consistent with a presynaptic explanation for use-dependent effects of dTC in extracellular experiments. In the B system, $1 \mathrm{~Hz}$ stimulation produced pure depression of EPSCs that gave way to facilitation at higher frequencies (Fig. 8A,C). Maximal depression occurred between 1 and $5 \mathrm{~Hz}$, and this corresponds well with the frequency dependence of extracellular fade in dTC (Fig. $2 E$ ). The incrcasc in $\mathrm{IC}_{50}$ for dTC between 5 and $20 \mathrm{~Hz}$ (Fig. $2 E$ ) is also consistent with the increase in facilitation seen at these frequencies in normal Ringer (Fig. 8A,C). There is a similar correlation in C cells between EPSC behavior in normal Ringer (Fig. 8B,D) and the use dependence of dTC in blocking synapses (Fig. 2). This supports the conclusion that dTC acts on postsynaptic nicotinic receptors, lowers the safety factor for transmission, and thereby unmasks the frequency dependence of $\mathrm{ACh}$ release by $\mathrm{B}$ and $\mathrm{C}$ cells.

One hypothesis to account for the difference in release is that quantal content is higher in preganglionic $\mathrm{B}$ neurons than in preganglionic $C$ neurons. If true, one might expect readily releasable stores of $\mathrm{ACh}$ to be quickly depleted in B cells at modest rates of repetitive stimulation. By contrast, the low level of release by $\mathrm{C}$ neurons would not deplete stores and, instead, release might be potentiated at low frequencies through intracellular $\mathrm{Ca}^{2+}$ accumulation. A model of this type also predicts posttrain depression in the $B$ system and posttrain potentiation in the C system (Figs. 3, 4).

The idea that quantal content can differ between subclasses of preganglionic terminals has precedents. Nishi et al. (1967) compared maximal rates of rise for miniature and evoked EPSPs in toad sympathetic ganglia and concluded quantal content was 129 in B cells and 79 in C cells, but they did not report the size of their samples. Although suggestive, the potential complexity of the problem is illustrated by a study in bullfrog of $39 \mathrm{~B}$ cells in which quantal content was quite variable, ranging from 21 to 125 (Connor et al., 1983). In the avian ciliary ganglion, Dryer and Chiappinelli (1987) reported quantal content was 15-30 in preganglionics innervating the larger, ciliary neurons and 4-7 in preganglionics innervating chorioid neurons.

\section{Do presynaptic receptors modulate ACh release?}

It is an old notion that mammalian and amphibian autonomic ganglia contain presynaptic nicotinic receptors (Koelle, 1961; Koketsu and Nishi, 1968; Ginsborg, 1971). The evidence in frog sympathetic ganglia comes from extracellular recordings of presynaptic action potentials. Reviewing earlier experiments, it is difficult to exclude the possibility that elevation of extracellular $\mathrm{K}^{+}$by activation of postsynaptic nicotinic receptors caused the reported presynaptic changes. Nonetheless, we saw no effects of dTC on evoked release of ACh or LHRH. This conforms with negative results in $\mathrm{ACh}$ collection experiments from mammalian ganglia (Brown et al., 1970). The case against presynaptic nicotinic receptors in $C$ neurons is weaker than that in $B$ neurons because we were unable to apply $\mathrm{ACh}$ iontophoretically at 20 $\mathrm{Hz}$ where fade occurs. Despite this limitation, two observations argue against presynaptic nicotinic receptors in $\mathrm{C}$ neurons. The depression of EPSC amplitude at $20 \mathrm{~Hz}$ in normal Ringer (Fig. $8 B$ ) resembled fade in dTC (Figs. 2, 4), and LHRH release by preganglionic $\mathrm{C}$ terminals was unaltered by dTC (Fig. 10).

Since dTC blocks potassium conductances in B cells (Goh and Pennfather, 1987), it might act presynaptically but in nonspecific fashion. This seems unlikely since dTC did not alter the rate of depression in the B system (Fig. 9). Moreover, structurally unrelated compounds (neuronal bungarotoxin, hexamethonium, mecamylamine) produce qualitatively similar effects on trains of CAPs (Shen and Horn, 1992, 1993).

Alternatively, presynaptic muscarinic receptors might contribute to differences between $\mathrm{B}$ and $\mathrm{C}$ cells. Based on recordings in low $\mathrm{Ca}^{2+}$, high $\mathrm{Mg}^{2+}$ Ringer, Koketsu and Yamada (1982) concluded that presynaptic muscarinic receptors inhibit $\Lambda \mathrm{Ch}$ re lease in the B system. However, Conner et al. (1983) concluded that presynaptic muscarinic receptors do not modulate quantal content in preganglionic B fibers.

Additional experiments will be needed to understand the difference in $\mathrm{ACh}$ release between preganglionic $\mathrm{B}$ and $\mathrm{C}$ neurons, and the physiological significance of these mechanisms for ganglionic integration and downstream control of glandular secretion and arterial tone.

\section{References}

Ascher P, Large WA, Rang HP (1979) Studies on the mechanism of action of acetylcholine antagonists on rat parasympathetic ganglion cells. J Physiol (Lond) 295:139-170.

Brown DA, Jones KB, Halliwell JV, Quilliam JP (1970) Evidence against a presynaptic action of acetylcholine during ganglionic transmission. Nature 226:958-959.

Connor EA, Levy SM, Parsons RL (1983) Kinetic analysis of atropineinduced alterations in bullfrog ganglionic fast synaptic currents. J Physiol (Lond) 337:137-158.

Corriveau RA, Berg DK (1993) Coexpression of multiple acetylcholine receptor genes in neurons: quantification of transcripts during development. J Neurosci 13:2662-2671.

DeLean A, Munson PJ, Rodbard D (1978) Simultaneous analysis of families of sigmoidal curves: application to bioassay, radioligand assay, and physiological dose-response curves. Am J Physiol 235:E97E102.

Derkach VA, North RA, Selyanko AA, Skok VI (1987) Single channels activated by acetylcholine in rat superior cervical ganglion. $\mathbf{J}$ Physiol (Lond) 388:141-151.

Dodd J, Horn JP (1983) A reclassification of B and C neurones in the ninth and tenth paravertebral sympathetic ganglia of the bullfrog. $\mathbf{J}$ Physiol (Lond) 334:255-269.

Dryer SE, Chiappinelli VA (1987) Analysis of quantal content and quantal conductance in two populations of neurons in the avian ciliary ganglion. Neuroscience 20:905-910.

Gibb AJ, Marshall IG (1984) Prc- and Post-junctional effects of tubocurarine and other nicotinic antagonists during repetitive stimulation in the rat. J Physiol (Lond) 351:275-297.

Ginsborg BL (1971) On the presynaptic acetylcholine receptors in sympathetic ganglia of the frog. J Physiol (Lond) 216:237-246.

Goh JW, Pennefather PS (1987) Pharmacological and physiological properties of the after-hyperpolarization current of bull-frog ganglion neurones. J Physiol (Lond) 394:315-330.

Gurney AM, Rang HP (1984) The channel-blocking action of methonium compounds on rat submandibular ganglion cells. Br J Pharmacol 82:623-642.

Harris AJ, Kuffler SW, Dennis MJ (1971) Differential chemosensitivity of synaptic and extrasynaptic areas on the neuronal surface membrane in parasympathetic neurons of the frog, tested by microapplication of acetylcholine. Proc R Soc Lond [Biol] 177:541-553.

Horn JP (1992) The integrative role of synaptic cotransmission in the bullfrog vasomotor $C$ system: evidence for a synaptic gain hypothesis. Can J Physiol Pharmacol 70:S19-S26.

Horn JP, Stofer WD (1988) Spinal origins of preganglionic B and C 
neurons that innervate paravertebral sympathetic ganglia nine and ten of the bullfrog. J Comp Neurol 268:71-83.

Jan LY, Jan YN (1982) Peptidergic transmission in sympathetic ganglia of the frog. J Physiol (Lond) 327:219-246.

Janig W, McLachlan EM (1992) Characteristics of function-spccific pathways in the sympathetic nervous system. Trends Neurosci 15: $475-481$.

Koelle GB (1961) A proposed dual neurochemical role of acetylcholine: its functions at the pre- and post-synaptic sites. Nature 190:208211.

Koketsu K, Nishi S (1968) Cholinergic receptors at sympathetic preganglionic nerve terminals. J Physiol (Lond) 196:293-310.

Koketsu K, Yamada M (1982) Presynaptic muscarinic receptors inhibiting active acetylcholine release in the bullfrog sympathetic ganglion. Br J Pharmacol 77:75-82.

Kuba K, Nishi S (1979) Characteristics of fast excitatory postsynaptic current in bullfrog sympathetic ganglion cells. Pfluegers Arch 378: 205-212.

Libet B, Chichibu S, Tosaka T (1968) Slow synaptic responses and excitability in sympathetic ganglia of the bullfrog. J Neurophysiol 31:383-395.

Lipscombe D, Rang HP (1988) Nicotinic receptors of frog ganglia resemble pharmacologically those of skeletal muscle. J Neurosci $8: 3258-3265$

Listerud M, Brussaard AB, Devay P, Colman DR, Role LW (1991) Functional contribution of neuronal AChR subunits revealed by antisense oligonucleotides. Science 254:1518-1521.

Luetje CW, Patrick J (1991) Both $\alpha$ and $\beta$-subunit contribute to the agonist sensitivity of neuronal nicotinic acetylcholine receptors. J Neurosci 11:837-845.

Luetje CW, Wada K, Rogers S, Abramson SN, Tsuji K, Heinemann S, Patrick J (1990) Neurotoxins distinguish between different neuronal acetylcholine receptor subunit combinations. J Neurochem 55:632640.

MacDermott AB, Connor EA, Dionne VE, Parsons RL (1980) Voltage clamp study of fast excitatory synaptic currents in bullfrog sympathetic ganglion cells. J Gen Physiol 75:39-60.

Magleby KL, Stevens CF (1972a) The effect of voltage on the time course of end-plate currents. J Physiol (Lond) 223:151-171.

Magleby KL, Stevens CF (1972b) A quantitative description of endplate currents. J Physiol (Lond) 223:173-197.

Magleby KL, Pallotta BS, Terrar DA (1981) The effect of (+)-tubocurarine on neuromuscular transmission during repetitive stimulation in the rat, mouse and frog. J Physiol (Lond) 312:97-113.

Marshall LM (1985) Presynaptic control of synaptic channel kinetics in sympathetic neurones. Nature 317:621-623.
Marshall LM (1986) Different synaptic channel kinetics in sympathetic $\mathrm{B}$ and $\mathrm{C}$ neurons of the bullfrog. J Neurosci 6:590-593.

Mathie A, Cull-Candy SG, Colquhoun D (1987) Single-channel and whole-cell currents evoked by acetylcholine in dissociated sympathetic neurons of the rat. Proc R Soc Lond [Biol] 232:239-248.

Mathie A, Cull-Candy SG, Colquhoun D (1991) Conductance and kinetic properties of single nicotinic acetylcholine receptor channels in rat sympathetic neurones. J Physiol (Lond) 439:717-750.

Nishi S, Soeda H, Koketsu K (1965) Studies on sympathetic B and C neurons and patterns of preganglionic innervation. J Cell Comp Physiol 66:19-32.

Nishi S, Soeda H, Koketsu K (1967) Release of acetylcholine from sympathetic preganglionic nerve terminals. J Neurophysiol 30:114134.

Papke RL, Heinemann SF (1991) The role of the $\beta_{4}$-subunit in determining the kinetic properties of rat neuronal nicotinic acetylcholine $\alpha_{3}$-receptors. J Physiol (Lond) 440:95-112.

Paton WDM, Zaimis EJ (1949) The pharmacological actions of bistrimethylammonium salts. Br J Pharmacol 4:381-400.

Peng Y-y, Horn JP (1991) Continuous repetitive stimuli are more effective than bursts for evoking LHRH release in bullfrog sympathetic ganglia. J Neurosci 11:85-95.

Rang HP (1982) The action of ganglionic blocking drugs on the synaptic responses of rat submandibular ganglion cells. Br J Pharmacol $75: 151-168$.

Sargent PB (1993) The diversity of neuronal nicotinic acetylcholine receptors. Annu Rev Neurosci 16:403-443.

Shen W, Horn JP (1992) Use-dependent actions of nicotinic blockers: are they presynaptic? Soc Neurosci Abstr 18:793.

Shen W-X, Horn JP (1993) Nicotinic antagonists distinguish between synapses on sympathetic B and C neurons in the bullfrog. Soc Neurosci Abstr 19:1532.

Skok VI, Selyanko AA, Derkach VA (1989) Molecular mechanisms underlying the effects of ganglion-blocking agents. In: Neuronal acetylcholine receptors, Chap 5. New York: Consultants Bureau.

Stofer WD, Fatherazi S, Horn JP (1990) Neuropeptide Y mimics a non-adrenergic component of sympathetic vasoconstriction in the bullfrog. J Auton Nerv Syst 31:141-152.

Vernallis AB, Conroy WG, Berg DK (1993) Neurons assemble acetylcholine receptors with as many as three kinds of subunits while maintaining subunit segregation among receptor subtypes. Neuron 10:451-464.

Zengel JE, Magleby KL, Horn JP, McAfee DA, Yarowsky PJ (1980) Facilitation, augmentation, and potentiation of sympathetic transmission at the superior cervical ganglion of the rabbit. J Gen Physiol 76: 213-231. 